\title{
Adnexal Masses Detected During Pregnancy: A Tertiary Center Experience
}

\author{
Gebelik Sirasında Tespit Edilen Adneksial Kitleler: \\ Bir Üçüncü Basamak Merkezin Deneyimi
}

\section{Esra Keles Peker ${ }^{1}$, Ugur Kemal Ozturk ${ }^{1}$, Burak Giray ${ }^{2}$, Serkan Akis ${ }^{1}$, Eser Sefik Ozyurek ${ }^{1}$, Canan Kabaca ${ }^{1}$, Murat Api ${ }^{1}$}

${ }^{1}$ University of Health Sciences, Department of Gynecologic Oncology, Zeynep Kamil Training and Research Hospital, Istanbul, Turkey.

${ }^{2}$ University of Health Sciences Turkey, Şehit Prof. Dr. İlhan Varank Sancaktepe Training and Research Hospital, Clinic of Obstetrics and Gynecology, Istanbul, Turkey.

\section{Yazısma Adresi / Correspondence:}

\section{Burak Giray}

University of Health Sciences Turkey, Şehit Prof. Dr. İlhan Varank Sancaktepe Training and Research Hospital, Clinic of Obstetrics and Gynecology, İstanbul, Turkey

$$
\text { T: +905055541590 E-mail : burakgiray@gmail.com }
$$

Geliş Tarihi / Received : 21.01.2021 Kabul Tarihi / Accepte: 04.12.2021

Orcid :

Esra Keles Peker https://orcid.org/0000-0001-8099-8883

Ugur Kemal Ozturk https://orcid.org/0000-0003-0720-2919

Burak Giray https://orcid.org/0000-0002-3832-6634

Serkan Akis https://orcid.org/0000-0003-0620-1500

Eser Sefik Ozyurek https://orcid.org/0000-0002-5373-3991

Canan Kabaca https://orcid.org/0000-0002-7069-279X

Murat Api https://orcid.org/0000-0001-9442-2690

( Sakarya Tip Dergisi / Sakarya Med J 2021, 11(4):751-756 ) DOI: 10.31832/smj.865975

\footnotetext{
Abstract

Objective We aimed to evaluate adnexal masses in pregnant women who were referred to the gynecologic oncology department.

Materials Data of the pregnant women referred to the gynecological oncology department between November 2016 and June 2019 with suspicion of adnexal malignancy were and Methods retrieved through the hospital's electronic medical records that included patients' demographic characteristics, gestational age, ultrasonographic, and magnetic resonance imaging findings, serum tumor markers, histopathological results. Patients with a spontaneously regressed adnexal mass, benign adnexal masses, and concurrent ectopic pregnancy were excluded.

Results The mean age of the patients was $30.9 \pm 0.87$ years. The mean gestational age at diagnosis was $14.05 \pm 1.36$ weeks and the mean gestational age at delivery was $35.9 \pm 1.23$ weeks. The mean gestational age at diagnosis was $14.05 \pm 1.36$ weeks. Twenty-five patients (59.5\%) underwent laparotomy while 18 patients $(40.5 \%)$ managed conservatively. The histopathological results were mucinous cystadenoma in $8(32 \%)$ patients, mature cystic teratoma in $6(24 \%)$ patients, borderline mucinous cystadenoma in $3(12 \%)$ patients, borderline serous cystadenoma in $2(8 \%)$ patients, serous cystadenoma in $2(8 \%)$ patients, Brenner's tumor in $2(8 \%)$ patients, theca lutein cysts in $1(4 \%)$ patient, and fibroma in $1(4 \%)$ patient. None of the patients has malignant neoplasm.

Conclusion Adnexal masses at pregnancy should be referred gynecologic oncology department after the 17th week of gestation.

Keywords adnexal mass; borderline ovarian tumor; pregnancy; teratoma
}

$\ddot{O z}$

Amaç Jinekolojik onkoloji bölümüne sevk edilen adneksiyal kitlesi olan gebeleri değerlendirmeyi amaçladık.

Gerec ve Jinekolojik onkoloji bölümüne Kastm 2016 ve Haziran 2019 tarihleri arasında sevk edilen șüpheli adneksial kitlesi olan gebelerin demografik özelliklerini, gebelik yasıın, ultrasonografik ve Yöntemle manyetik rezonans görüntüleme bulgularıı, tümör markerlarııı ve histopatolojik sonuçlarını içeren verileri hastane veri tabanı kullanılarak toplandı. Spontan regrese olan kitleler, benign adneksial kitleler ve eș zamanl ektopik gebeliği olan hastalar çalıșma dışı bırakıldı.

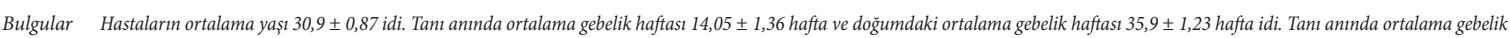
haftası 14,05 $\pm 1,36$ hafta idi. Yirmi beș hastaya $(\% 59,5)$ laparotomi yapıllırken, 18 hastaya $(\% 40,5)$ konservatif tedavi uygulandı. Histopatolojik sonuçlar $8(\% 32)$ hastada müsinöz kistadenom, 6 (\%24) hastada matür kistik teratom, 3 (\%12) hastada borderline müsinöz kistadenom, 2 (\%8) hastada borderline seröz kistadenom, 2 (\%8) hastada seröz kistadenom, 2 (\%8) hastada Brenner tümörü, 1 (\%4) hastada teka lutein kisti, 1 (\%4) hastada ise fibroma idi. Hastaların hiçbirinde malign adneksial kitleye rastlanmad. 


\section{INTRODUCTION}

Adnexal masses are not common during pregnancy. The reported incidence and detection rates of adnexal masses has increased with the widespread use of ultrasonography in routine antenatal screening. The management of adnexal mass in pregnancy has been controversial in guidelines for years, and there is no consensus on the management. In general, diagnosis of an adnexal mass in pregnancy is incidental, and adnexal mass is revealed on routine pregnancy follow-up. The prevalence of adnexal mass in pregnancy is 1 per 76 to 2328 deliveries and adnexal masses persist in $0.7-1.4 \%{ }^{1-3}$ An adnexal mass during pregnancy is mostly asymptomatic, benign and spontaneously resolved before the 16th week of gestation; after the 16th week, many complications such as ovarian torsion, cyst rupture, labor obstruction can occur. ${ }^{2,4,5}$ Ultrasonography (US), magnetic resonance imaging (MRI), and tumor markers have limited benefits to differentiate between benign and malignant ovarian tumors. ${ }^{6}$

The purpose of this study is to evaluate comparatively adnexal masses in pregnancy who were referred to gynecologic oncology department.

\section{MATERIAL and METHODS}

Forty-three pregnant women with adnexal mass who were referred to the gynecological oncology department in a tertiary center were included in the study between November 2016 and June 2019.

The pregnant women who referred to gynecologic oncology department due to suspicion of adnexal malignancy enrolled in this study. Gynecologic oncology board and hospital records of the patients were examined and reviewed retrospectively. The data including maternal age, parity, gravity, gestational age at diagnosis, gestational age at surgery and delivery, ultrasonographic appearance, MRI findings, histopathological diagnosis, serum tumor markers and final histopathology of adnexal masses were collected. Patients with spontaneously regressed adnexal mass were excluded. Adnexal masses concurrent with ectopic pregnancies were also excluded. None of the newborns had a congenital anomaly. None of the patients had a pregnancy-related disorder. The patients gave informed and voluntary consent to the publication of her clinical data and they have agreed to participate in this manuscript. Informed consent was obtained in obedient to declaration of Helsinki. The current study was approved by the Zeynep Kamil Training and Research Hospital Ethical Committee (date: 06.05.2020, approval number: 92).

Mean diameter of the adnexal mass was calculated dividing the sum of three diameters by three. Cyst volume was calculated using the simplified formula: $0.5 \times$ length $\times$ widthxthickness (LxHxWx0.5).

Statistical data were analyzed using Statistical Package for Social Sciences (SPSS) version 22. Continuous variables were described as mean \pm SD and categorical data were expressed in number and percentage. Analysis of the characteristics of patients was performed using descriptive studies.

\section{RESULTS}

Adnexal mass was detected in 43 pregnant women during antenatal follow-ups between November 2016 and June 2019. The mean age of the patients was $30.9 \pm 0.87$ years. The median gravidity was 2 (range, 1-4) and the median parity was 1 (range, $0-4$ ) at the time of diagnosis. The mean gestational age at diagnosis was $14.05 \pm 1.36$ weeks (range, 5-38 weeks) and the mean gestational age at delivery was 35.9 \pm 1.23 weeks (range, 14-41 weeks) (Table 1). The demographic data and outcome data did not differ significantly between borderline and benign adnexal mass groups.

The mean diameter of adnexal masses was $88.57 \pm 7.71$ $\mathrm{mm}$ (range, $30-236 \mathrm{~mm}$ ) and the mean cyst volume was $607.51 \pm 166.77 \mathrm{~mm} 3$ (range, $5-5843 \mathrm{~mm} 3$ ). The mean volume of the borderline adnexal mass was $1262 \mathrm{~cm} 3$ and the 
mean volume of benign cysts was $548.6 \mathrm{~cm} 3(\mathrm{p}=0.568)$. $47.5 \%$ of the adnexal masses were detected on the left side, $42.5 \%$ of the adnexal masses were detected on the right side, and $10 \%$ of the adnexal were detected bilaterally.

\begin{tabular}{|c|c|}
\hline & $n=43$ \\
\hline Age (years) & $30.90 \pm 0.86$ \\
\hline Gravida & $2(1-4)$ \\
\hline Parity & $1(0-4)$ \\
\hline Gestational age at diagnosis (weeks) & $14.05 \pm 1.36(5-38)$ \\
\hline Gestational age at delivery (weeks) & $35.9 \pm 1.23(14-41)$ \\
\hline Cyst volume (cm3) & $607.51 \pm 166.77$ \\
\hline Cyst size (mm) & $88.57 \pm 7.71$ \\
\hline CA $125(\mathrm{U} / \mathrm{ml})$ & $37.94 \pm 5.42$ \\
\hline LDH (U/L) & $186.6 \pm 9.24$ \\
\hline $\operatorname{AFP}(\mathrm{ng} / \mathrm{ml})$ & $50.29 \pm 14.61$ \\
\hline \multicolumn{2}{|c|}{$\begin{array}{l}\text { Values are presented as mean } \pm \text { SD and median (minimum-max- } \\
\text { imum). } \\
\text { AFP: Alpha fetoprotein; CA } 125 \text { : cancer antigen } 125 \text {; LDH: lactate } \\
\text { dehydrogenase. }\end{array}$} \\
\hline
\end{tabular}

The mean CA 125 level was $37.94 \pm 5.42 \mathrm{U} / \mathrm{mL}$ and $33.3 \%$ of them were above $35 \mathrm{U} / \mathrm{ml}$. The CA 125 serum levels were $28.2 \mathrm{U} / \mathrm{ml}$ and $39.38 \mathrm{U} / \mathrm{ml}$ for patients with borderline adnexal mass and benign cysts, respectively $(\mathrm{p}=0.198)$. The mean alpha fetoprotein (AFP) level was 50.29 \pm 14.61 $\mathrm{ng} / \mathrm{ml}$. The mean AFP levels of the borderline and benign adnexal masses were $23.7 \pm 7.3 \mathrm{ng} / \mathrm{ml}$ and $111 \pm 76.3$, respectively.

The mean gestational age at diagnosis was $14.05 \pm 1.36$ weeks (range: 5-38). Of 43 cases with adnexal masses, 24 patients $(55.8 \%)$ diagnosed in the first trimester, 8 patients (18.6\%) in the second trimester and 11 patients (25.6\%) third trimester.

Twenty-five patients (59.5\%) underwent laparotomy while 18 patients $(40.5 \%)$ managed conservatively. The mean gestational age of the patients managed conservatively was $35.7 \pm 1.3$ weeks at delivery. The mean gestational age of the patients underwent laparotomy was $38.5 \pm 0.5$ weeks at delivery.

The histopathologic results of the adnexal masses were shown in Table 2. The histopathological results were dermoid cyst in $6(24 \%)$ patients, mucinous cystadenoma in $8(31.9 \%)$ patients, serous cystadenoma in $2(8 \%)$ patients, borderline serous cystadenoma in $2(8 \%)$ patients, borderline mucinous cystadenoma in $3(11.9 \%)$ patients, Brenner's tumor in $2(8 \%)$ patients, fibroma in $1(4 \%)$ patient, and theca lutein cysts in 1 (4\%) patient (Table 2). None of the patients has malignant neoplasm.

\begin{tabular}{|l|c|}
\hline \multicolumn{2}{|l|}{ Table 2: Histopathologic results of the adnexal masses. } \\
\hline \multicolumn{2}{|l|}{$\mathbf{n = 2 5}$} \\
\hline Non-neoplastic group (n=12) & $8(32 \%)$ \\
\hline Mucinous cystadenoma & $2(8 \%)$ \\
\hline Serous cystadenoma & $1(4 \%)$ \\
\hline Theca-lutein cyst & $1(4 \%)$ \\
\hline Fibroma & \\
\hline Neoplastic group (n=13) & $6(24 \%)$ \\
\hline Mature cystic teratoma & $3(12 \%)$ \\
\hline Borderline mucinous cystadenoma & $2(8 \%)$ \\
\hline Borderline serous cystadenoma & $2(8 \%)$ \\
\hline Brenner's tumor &
\end{tabular}

\section{DISCUSSION}

Reported incidence and detection rates of adnexal masses discovered during pregnancy have increased throughout the years with the common use of ultrasonography. Therefore, it carries crucial importance to direct the management of adnexal masses appropriately and safely during pregnancy. In the literature, the reported gestational week of diagnosis of adnexal masses mostly the first trimester of pregnancy. ${ }^{2,7-9}$ In accordance with the literature; our study showed $55.8 \%$ of adnexal mass diagnosed during first trimester.

In most studies, the histopathological distribution of adnexal masses encountered during pregnancy $28-35 \%$ dermoid cysts, followed by $16-24 \%$ cystadenomas, $2.15-13.5 \%$ 
borderline ovarian tumors, respectively. ${ }^{2}$ In our study, consistent with the literature; histopathological results were as follows: $24 \%$ mature cystic teratomas constitutes of $46.2 \%$ of neoplastic lesions, $40 \%$ cystadenomas, $20 \%$ borderline ovarian tumors.

The incidence of adnexal masses during pregnancy ranges from $1 / 81$ to $1 / 8000$ pregnancies. ${ }^{4}$ Since only complicated adnexal mass with suspected malignancy is consulted to gynecologic oncology department, we are unable to give an incidence in our study.

In previous studies, when discriminating of benign and malignant ovarian tumor, cyst size, cyst laterality, cyst features in US and MRI, tumor markers such as CA125, patients' demographic features have been studied. ${ }^{10,11}$ In this report, differentiate between benign lesions from malignant ones; patients demographic characteristics, cyst size, cyst volume, serum CA125 level, mean birth date were analyzed. It is interesting to note that, the diagnosed gestational week of adnexal mass was significant, but the operated gestational was not found significant. As far as we know, CA125 have a limited role in evaluating the adnexal mass, which distinguishes between malignant and benign ovarian lesions. ${ }^{2,9,12}$ CA125 values are commonly elevated in the first trimester, normalize in the second trimester and remain low until delivery. ${ }^{13}$ Although uncommon, CA125 can be elevated during the third trimester in the absence of malignancy. ${ }^{1,11}$

Conservative management of adnexal masses $<5-6 \mathrm{~cm}$ in diameter is supported by literature. ${ }^{14}$ As our study indicated that cyst size is not a significant parameter about assessing malignancy. The most striking point of our study is that many authors analyzed adnexal cyst by calculating the size of the cyst cm in diameter and making an inference. ${ }^{15}$ Our study is remarkable in this respect and in the current study we have calculated cyst volume. The mean cyst diameter was $8.8 \pm 7.7 \mathrm{~cm}$ and the mean cyst volume was $607 \pm 166 \mathrm{~mm} 3$, but no appreciable differences were found.
Since our findings are based on a small number of patients, we obtain unsatisfactory results from this analysis.

Our study also shows that if surgery is required, it can be safely performed; as our data demonstrates that there is no difference between the operated patients and the patients undergoing laparotomy in terms of birth weeks.

We aware that our research may have two limitations. The first is a small number of patients due to our facility center is a tertiary referral center and benign adnexal masses followed by obstetricians. Only patients referred to the gynecologic oncology department and discussed in the tumor boards were included in our study. Second is the retrospective design of the study. Prospective studies with including multiple institutions may help to develop a successful management plan of adnexal masses during pregnancy.

In conclusion, the common tendency would be to delay diagnosis of a suspected adnexal mass until the first trimester, namely 13 weeks 6 days; however, our findings suggest that the commencement of oncologic follow up is 17 weeks of gestation. Probably the follow-up of adnexal mass as a suspect of malignant pathology should be consulted to the gynecologic oncology department after 17th weeks of pregnancy.

\section{Ethical committee approval}

The current study was approved by the Zeynep Kamil Training and Research Hospital Ethical Committee (date: 06.05.2020, approval number: 92).

\section{Conflict of Interest}

No conflict of interest was declared by the authors.

\section{Financial Disclosure}

The authors declared that this study has received no financial support. 
Sakarya Med J 2021;11(4):751-756

PEKER et al., : Adnexal Mass In Pregnancy

\section{Informed consent}

Informed consent was obtained from all individual parti-

cipants included in the study. 
Sakarya Med J 2021;11(4):751-756

PEKER et al., : Adnexal Mass In Pregnancy

\section{Kaynaklar}

1. Korenaga TK, Tewari KS. Gynecologic cancer in pregnancy. Gynecol Oncol 2020;157(3):799809 .

2. Aggarwal P, Kehoe S. Ovarian tumors in pregnancy: A literature review. Eur J Obstet Gynecol Reprod Biol 2011;155:119-24.

3. Goh W, Bohrer J, Zalud I. Management of the adnexal mass in pregnancy. Curr Opin Obstet Gynecol 2014;26(2):49-53.

4. Whitecar MAP, Turner S, Higby MK. Adnexial masses in pregnancy: A review of 130 cases undergoing surgical management. Am J Obstet Gynecol 1999;181(1):19-24.

5. Bernhard LM, Klebba PK, Gray DL, Mutch DG. Predictors of persistence of adnexal masses in pregnancy. Obstet Gynecol 1999;93:585-9.

6. Yacobozzi M, Nguyen D, Rakita D. Adnexal masses in pregnancy. Semin Ultrasound CT MR 2012;33:55-64.

7. Ueda M, Ueki M. Ovarian tumors associated with pregnancy. Int J Gynaecol Obstet 1996;55:59-65.

8. Kwon YS, Mok JE, Lim KT, Lee IH, Kim TJ, Lee KH, et al. Ovarian cancer during pregnancy: clinical and pregnancy outcome. J Korean Med Sci 2010; 25(2):230-234.

9. Balci O, Gezginc K, Karatayli R, Acar A, Celik C, Colakoglu MC. Management and outcomes of adnexal masses during pregnancy: A 6-year experience. J Obstet Gynaecol Res 2008;34(4):524-8.
10. Webb K, Sakhel K, Chauhan S, Abuhamad A. Adnexal mass during pregnancy: a review. Am J Perinatol 2015;32(11):1010-6.

11. Ercan Ş, Kaymaz Ö, Yücel N, Orçun A. Serum concentrations of CA 125, CA 15-3, CA 19-9 and CEA in normal pregnancy: A longitudinal study. Arch Gynecol Obstet 2012;285(3):579-84.

12. Boussios S, Moschetta M, Tatsi K, Tsiouris AK, Pavlidis N. A review on pregnancy complicated by ovarian epithelial and non-epithelial malignant tumors: diagnostic and therapeutic perspectives. J Adv Res 2018;12:1-9.

13. Han SN, Lotgerink A, Gziri MM, Van Calsteren M, Hanssens M, Amant F. Physiologic variations of serum tumor markers in gynecological malignancies during pregnancy: A systematic review. BMC Med 2012;10(1):86

14. Platek DN, Henderson CE, Goldberg GL. The management of a persistent adnexal mass in pregnancy. Am J Obstet Gynecol 1995;173:1236-40.

15. Zou G, Xu P, Zhu L, Ding S, Zhang X. Comparison of subsequent pregnancy outcomes after surgery for adnexal masses performed in the first and second trimester of pregnancy. Int Gynaecol Obstet. 2020;148(3):305-9. 